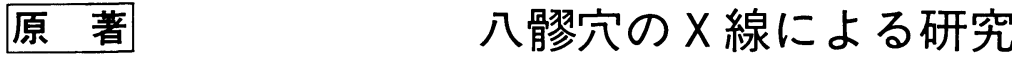

\author{
橋口利 彰* 木下 晴 都
}

要旨 八髎穴の取穴法として 23 人の仙骨部をX 線で研究した。第 5 腰 椎棘突起と中仙骨稜上緑との中央を「十七椎」と定め, 左右の仙骨角下 縁の中央を「仙骨角中点」とする。

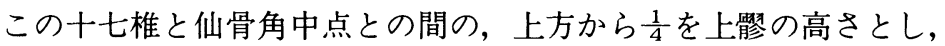
さらに同じ間で下から $\frac{1}{10}$ 高さを下髎の高さとする。上髎と下髎の間 を 3 等分して次髎, 中骼の高さとする。

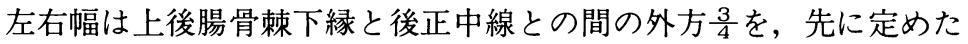
上髎の高さと交わらせ上髎の位置とする。同じく上後腸骨棘下縁と後 正中線との間の $\frac{1}{2}$, 先に定めた下髎の高さと交わらせ下髎の位置と する。次に上髎と下髎を斜線で結び, 上記次䯍・中髎の高さと交わら せ，次髎・中骨の位置とする。

\section{I はじめに}

仙骨後面にある4対の八䋚穴は,「素問」尚骨空論に "在八髎腰尻分間" と記載されているが，それは泌 尿器，婦人科疾患などに使用瀕度の高い経穴であ る。後仙骨部は両側から寛骨が高く覆いかぶさり， その上に筋，腱，靸帯などが付着しているため， 仙骨部の取穴はしばしば間違いを生じやすい部位 である。

古典に記載された八賿穴の部位を考証すると， 後仙骨孔とは 1 椎のずれがあり，また解剖学の未 発達な時代には，仙骨を見た経験はあったとして も臨床上の取究にあたっては，いずれに八骴穴を 定めたかは疑問の残るところである。しかし，近 年は後仙骨孔を対象に取穴するのが一般的に普及 されている。

ところが取穴の割り込みをみると，その割り込

* Toshiaki HASHIGUCHI 東京医療専門学校銊炎教員養成科 共同研究者：Haruto KINOSHITA 点竹学園東洋医学臨床研 究所

Key Words：八髎穴, X 線による後仙骨孔, 仙骨部の経穴
みには統一がなく，しかもそれを明らかにした研 究も少ない。目下, 日本経究委員会では経穴の標 準部位を定めるため, 経穴の部位について再検討 が加えられているところであり，これをより客観 性のある表現に接近することを目的として，X線 により後仙骨孔の位置を確め，八䯘穴を合理的に 配分できる方法を研究した。

\section{II 研究方法}

八翠穴を体表解剖学的に取穴するには，まず後 仙骨孔をX線学的に証明し，外表の基準点との関 係を明らかにしなければならない。

研究対象は骨盤に著明な奇形, 変形のない協力 者をランダムに選んだ。それらの対象に体表上か ら触知できる基準点を定め，これに金属マークを 貼付して仙骨部のX線撮影を行った。そのマーク 部位として，上部は第 5 腰椎棘突起下縁と中仙骨 稜上縁との中央を十七椎と呼び，下部は仙骨角下 縁の左右の中央を仙骨角中点と呼ぶことにした。

また左右の上後腸骨棘下縁を腸棘下点と呼ぶ。 以上の 4 か所に金属マークを貼付するが体位は腹 臥位で定め，X線撮影時はフィルム面との誤差を 
小さくするため, 被検者は仰臥位にした。光源は フィルム面に対し $2 \mathrm{~m}$ の高さから照射し，光源は 左右の上前腸骨棘の中央にセットした。その結果， 実寸 $100 \mathrm{~mm}$ に対し $1 \mathrm{~mm}$ の拡大しかなく, X 線写 真を実寸とみなして研究した。

なお，第 1 後仙骨孔から第 4 後仙骨孔までを， 第 1 孔ないし第 4 孔と呼ぶ。さらに経穴の配分に あたり，基準の長さを比較配分するときは Practical Professional Unit (実用的比率単位), 略して PPUを付けることにする。

\section{III 八骨翏穴と後仙骨孔との関係}

八髎穴の部位を後仙骨孔にできる限り近接して 定める目的で，仙骨部の X 線撮影を 23 人 (男 : 12 , 女：11)について行ったが, Table.1に示すとおり その平均年秢は 46 歳であり，平均身長は $160 \mathrm{~cm} \pm$ $10 \mathrm{~cm}$ であり，平均体重は $57 \pm 9 \mathrm{~kg}$ であった。
a）X線からみた後仙骨孔の上下間隔

仙骨部周辺に基準点を定めて撮影したX 線写真 はFig. 1 に示すとおりであるが，このマーク間の 距離について人体を実測した長さと，X線写真を 実測した長さとの間には $100 \mathrm{~mm}$ に対し $1 \mathrm{~mm}$ の誤 差がみられたのみであった。これは仙骨角が約 150 に前傾するために，実体との差が僅少に撮影でき たものと思われる。

これらのX線写真を調べると，後仙骨孔がとき に不鮮明な場合もあったが，第 1 後仙骨孔と第 4 後仙骨孔は一般的に明瞭であった。この後仙骨孔 の大きさを実測すると，大小種々あったが直径 5 〜 $8 \mathrm{~mm}$ であり, 以前に木下 ${ }^{2}$ が20体(男: 10, 女 :10)の仙骨について計測した数值とほぼ一致した。

そこで後仙骨孔の上下間隔について実測した值 は，Table. 1 に示すとおりであったが，この垂直 距離の平均值をFig. 2 に表すと，十七椎と仙骨角

Table. 1 後仙骨孔間の寸法

$(\mathrm{N}=23) \quad($ 単位 $\mathrm{mm})$

\begin{tabular}{|c|c|c|c|c|c|c|c|c|c|c|c|c|c|c|c|c|c|c|c|c|c|c|c|c|c|}
\hline 氏 名 & To & GN & $\mathrm{HN}$ & $\mathrm{TH}$ & S I & $\mathrm{HH}$ & K K & Y K & G K & H K & NT & $\mathrm{KN}$ & HS & $\mathrm{J} \mathrm{H}$ & YM & $\mathrm{SN}$ & so & KY & $\mathrm{H} \mathrm{H}$ & $\mathrm{ST}$ & $\mathrm{MH}$ & MY & $\mathrm{Hz}$ & \multirow{2}{*}{ 平 均 } & \multirow{2}{*}{ 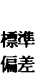 } \\
\hline 男· 女 & $0^{7}$ & $\sigma^{\pi}$ & $\sigma^{\top}$ & $0^{x}$ & $\sigma^{7}$ & $\sigma^{7}$ & $\sigma^{7}$ & $\sigma^{7}$ & $\sigma^{7}$ & $\sigma^{x}$ & $\sigma^{7}$ & $0^{x}$ & 우 & 우 & 우 & 우 & 우 & 우 & 우 & 우 & 우 & 우 & 우 & & \\
\hline 身長 $\mathrm{cm}$ & 155 & 159 & 160 & 161 & 183 & 171 & 165 & 164 & 173 & 175 & 168 & 162 & 150 & 151 & 165 & 158 & 158 & 152 & 151 & 154 & 146 & 149 & 151 & 160.0 & 9.5 \\
\hline 体重kg & 58 & 55 & 67 & 58 & 69 & 70 & 61 & 64 & 71 & 73 & 63 & 54 & 48 & 45 & 53 & 55 & 54 & 49 & 45 & 52 & 45 & 48 & 56 & 57.0 & 8.8 \\
\hline 十七椎一仙骨角中点 & 118 & 98 & 97 & 95 & 92 & 124 & 117 & 120 & 112 & 90 & 132 & 104 & 120 & 104 & 103 & 122 & 92 & 98 & 69 & 103 & 79 & 84 & 95.5 & 103.0 & 15. 7 \\
\hline 陽 関一一第 1 孔 & 45 & 46 & 53.5 & 51 & 47 & 55 & 56.5 & 54 & 60 & 51 & & 50 & 48.5 & 50 & 50 & 55 & 47 & 47.5 & 50 & 45 & 37 & 49 & 52 & 49. 6 & 4. 8 \\
\hline 十七椎一一第 1 孔 & 23 & 35 & 26 & 27 & 22 & 31.5 & 41 & 27 & 30 & 20 & 28 & 27 & 21 & 26 & 20 & 31 & 25 & 24 & 27.5 & 24 & 20 & 25 & 29 & 26.5 & 5.0 \\
\hline 第 1 孔一第 2 孔 & 37 & 20 & 25 & 21 & 17 & 20 & 34 & 22 & 30 & 25 & 25 & 22 & 20 & 30 & 30 & 24 & 15 & 24 & 16 & 20 & 15 & 18 & 17 & 22. 9 & 6.0 \\
\hline 第2 孔一一第3 & 29 & 19 & 24 & 19 & 23 & 22 & 25 & 22 & 20 & 28 & 28 & 24 & 25 & 21 & 18 & 25 & 17 & 23 & 17 & 20 & 22 & 15 & 20 & 22.0 & 3.7 \\
\hline 第 4 孔一仙骨角中点 & 9 & 13 & 10 & 8 & 5 & 4 & 3 & 5 & & 12 & 4 & 9 & 10 & 5 & 5 & 22 & 10 & 10 & 4 & 14 & & 7 & 9 & 8.5 & 4. 5 \\
\hline 仙骨管裂孔一仙骨角 & 34 & 16 & 14 & 15 & 14 & 19 & 18.5 & & 8 & 35 & 28 & 36 & 34 & 13 & 58 & 25 & 19 & 18 & 5 & 22 & 12 & 0 & 30 & 22.5 & 12.2 \\
\hline 腸蕀下点一後正中線 & 34 & 34 & 33 & 38 & 46 & 38 & 38 & 35 & 30 & 38 & 40 & 38 & 36 & 36 & 47 & 41 & 46 & 46 & 36 & 41 & 40 & 37 & 37 & 38.5 & 4.5 \\
\hline 第 1 孔一一後正中線 & 24 & 22 & 23 & 24 & 27 & 21 & 23 & 22 & 23 & 21 & 24 & 23 & 22 & 24 & 28 & 17 & 25 & 25 & 21 & 21 & 23 & 24 & 24 & 23.1 & 2.2 \\
\hline 第 2 孔一後正中楾 & 21 & 22 & 21 & 19 & 24 & 22 & 23 & 19 & 23 & 21 & 23 & 22 & 23 & 21 & 22 & 20 & 22 & 25 & 19 & 22 & 24 & & 24 & 21.9 & 1.7 \\
\hline 第3孔一一後正中楾 & 20 & 20 & 20 & 19 & 22 & 20 & 20 & 19 & 19 & 20 & 20 & 18 & 21 & 19 & 19 & 17 & 21 & 21 & 18 & 18 & 18 & 21 & 19 & 19. 5 & 1.2 \\
\hline 第 4 孔一一後正中線 & 17 & 19 & 16 & 18 & 19 & 15 & 16 & 18 & 17 & 18 & 17 & 18 & 15 & 15 & 17 & 15 & 14 & 20 & 13 & 17 & 18 & 17 & 18 & 16.8 & 1.7 \\
\hline$a$ 腸楝下点一第 2 孔 & 18.5 & 12.5 & 21 & 13 & 13 & 5.5 & 22.5 & 10 & 24 & 24 & 8 & 9 & 6.5 & 18.5 & 30 & 12 & 9 & 21 & 16 & 16 & 14 & 4 & 8 & 14.6 & 6.9 \\
\hline b第 1 孔一第 2 孔 & 37 & 20 & 25 & 21 & 17 & 20 & 34 & 22 & 30 & 25 & 25 & 22 & 20 & 30 & 30 & 24 & 15 & 24 & 16 & 20 & 15 & 18 & 17 & 22.9 & 6.0 \\
\hline
\end{tabular}




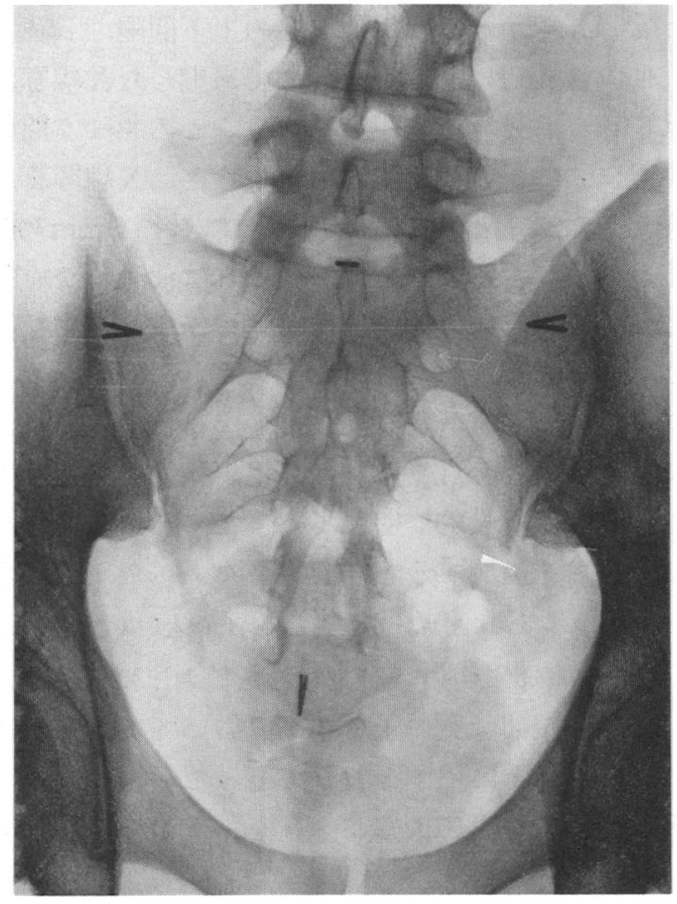

Fig. 1 仙骨部のX 線写真 ( 1 ・32歳)

Table. 2 仙骨部寸法

$(\mathrm{n}=23$ 单位 $=\mathrm{mm})$

\begin{tabular}{l}
\multicolumn{2}{|c|}{ 腰命一仙骴 } & 15 & 2 & 12 & 9 & 13 & 11 & 6 & 3 & 9 & 22 & 11 & \\
\hline
\end{tabular}

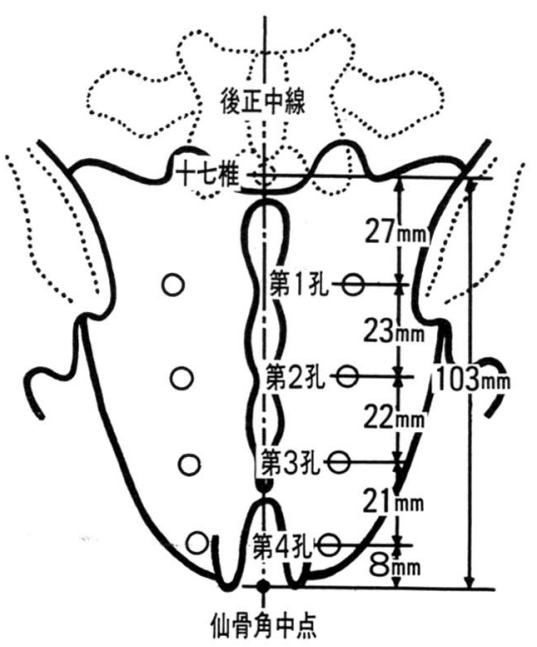

Fig. $2 X$ 線による後仙骨孔の上下間隔
中点との間は平均 $103 \pm 15.7 \mathrm{~mm}$ であった。次に各 後仙骨孔の上下間隔をみると，十七椎と第 1 孔の 間は26.5 $55.0 \mathrm{~mm}$ ，第 1 孔と第 2 孔の間は $22.9 \pm$ $6.0 \mathrm{~mm}$, 第 2 孔と第 3 孔の間は $22.0 \pm 3.7 \mathrm{~mm}$, 第 3 孔と第 4 孔の間は $21.5 \pm 3.4 \mathrm{~mm}$, 第 4 孔と仙骨 角中点との間は $8.5 \pm 4.5 \mathrm{~mm}$ であった $(F i g . ~ 2) 。$

なお腰金は仙骨管裂孔の部にある経穴として重 要であるが，この経穴は䯣空とも呼ばれ，「銊炎甲 乙経 $\left.{ }^{3)}\right\lrcorner に "$ 在第二十一椎節下間”としており，第 4 後仙骨孔の高さ，すなわち下骨の高さと並ぶ。「十 四経和語鈔」 ${ }^{4)}$ に゙二十一椎ノ下，亀尾ノ上, 二節ノ 間ナリ”と記すように, 左右の仙骨角の間に指を入 れてとどまるところを腰俞と定妨れるが，この 仙骨管裂孔を擦上して指の止まる深さを調べると， 仙骨角中点から $8.4 \mathrm{~mm} \pm 5.0 \mathrm{~mm}$ であった。

したがって腰俞は第 5 腰椎棘突起下縁と中仙骨 稜上縁との間にあたる十七椎と左右仙骨角中点と の間で下方から PPU $\frac{1}{10} に$ 定めることができる(Table. 2 )。

b ） X 線からみた後仙骨孔の水平間隔

X線写真により後仙骨孔中央の左右間が何ほど あるかを示したのがTable. 1 であるが，後正中線 から何ほどの距離にあるかを計測すると，Fig. 3 に示すように後正中線との水平距離の平均は，第 1 孔が $23.1 \pm 2.2 \mathrm{~mm}$ であり，第 2 孔が $21.9 \pm 1.7$

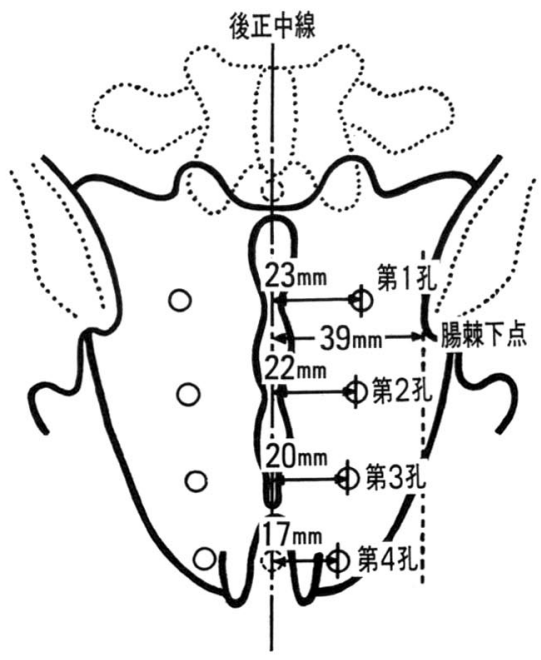

Fig. $3 X$ 線による後仙骨孔の水平間隔 


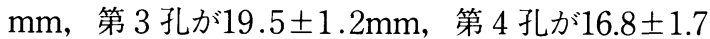
mmであった。

また水平距離の基準になる後正中線と腸棘下点 との間は $38.5 \pm 4.5 \mathrm{~mm}$ であった。

c ）後仙骨孔に対する八髎穴の配分

上述の後仙骨孔の上下間隔を基にして八髎穴を 配分する高さは, Fig. 4 の右側に示す方法を用い る。まず，十七椎と仙骨角中点までの距離(103mm) を基準にして，十七椎からPPU $\frac{1}{4}$ が上彫の高さに 相当する。後仙骨孔はある程度の大きさをもって いるため，ほぼ第 1 孔に一致する。

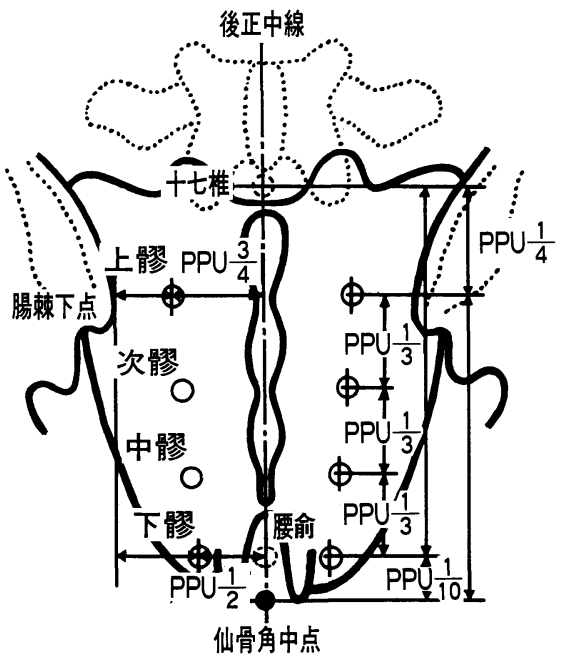

Fig. 4 後仙骨孔に対する八髎穴の配分

また十七椎と仙骨角中点との間で，仙骨角中点 からPPU $\frac{1}{10}$ は下䯎の高さに相当する。この場合も 後仙骨孔は大きいため，ほぼ第 4 孔と一致する。 次に上髎と下髎の高さを基準にして，その間を 3 等分して次骨と中骨翏を割り込めば，後仙骨孔の第 2 孔と第 3 孔にほぼ一致する。

次にX線写真による後正中線と腸棘下点との距 離を基準にして，八䡴穴をどのように割り込むか を検討した。それはFig. 4 の左側に示すように， 後正中線と腸棘下点との距離 $(38.5 \mathrm{~mm})$ を基準に して, 後正中線の外方 PPU $\frac{3}{4}$ 上髎と定めれば, 第 1 孔にほぼ相当することが判明した。後正中線 と腸棘下点との基準距離の中央で，下髎の高さと
交わる部を下髎と定めれば，ほぼ第 4 孔に相当す ることがわかった。

さらに上髎と下髎を基準にして斜線を仮定し, 先に定めた次髎と中髎の高さにあたる交点に，次 髎と中骨翏の部位を定めれば，ほぼ第 2 孔と第 3 孔 に一致する。

d ）後腸棘点を基準にする八䯈穴

八骨翏穴の高さを決定する時，上後腸骨棘の最高 点すなわち後腸棘点を対象に定める方法がしばし ば採用されている。後腸棘点を基準に次髎を定め る方式が次のように記されており，いずれも第 2 孔に当てはめている。

ア. 腸骨後上棘下端と第 2 仙骨仮状突起との中 間 $^{5)}$

イ。上後腸骨棘の内下方 3,4 分の陥凹に取る ${ }^{6)}$

ウ. 約当髂后上棘下与督脈之中点 ${ }^{7)}$

この方法の真偽を明らかにするために次の研究 を行った。

腸棘下点からみて第 2 孔は下方へ $14.6 \pm 6.9 \mathrm{~mm}$ の位置にあるが，最短 $4 \mathrm{~mm}$ から最長 $30 \mathrm{~mm}$ とバ ラツキが多かった。第 1 孔と第 2 孔の間で腸棘下 点の位置をみると，第 2 孔の高さを 0 として第 1 孔を 100 とすると第 2 孔から平均63の所にあった。 つまり，第 1 孔に近かった(Fig. 5 )。

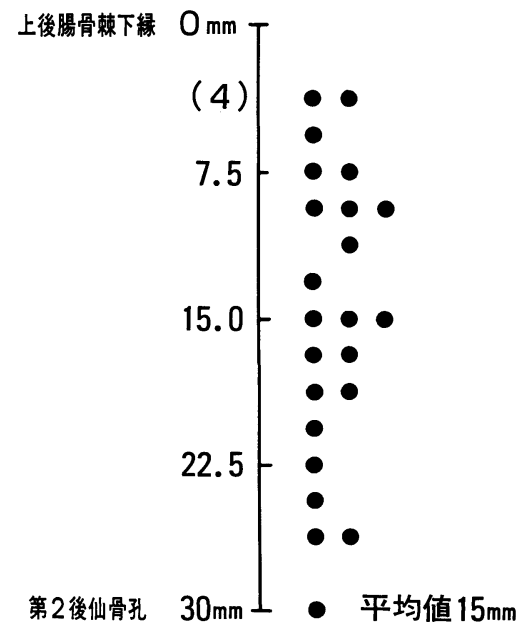

$$
\mathrm{n}=23
$$

Fig. 5 上後腸骨棘下縁に対する第2後仙骨孔の位置 


\section{IV 考察}

古典に記載された八爾穴の部位を考証すると， 体表に取穴するときの見解と，仙骨を実際に見た ときの見解に分かれるが，この両者の意見が果た して一致しているか否かについては疑問の残ると ころである。共同研究者の木下 ${ }^{2)}$ は 1955年 (S. 30 年)に八骴穴の古典部位と人骨格を研究したところ, 上髎穴は「甲乙経」゙)に゙在第一空，腰髁下一寸，俠 脊陥者中”からみて, 腰髁を腸骨稜とすれば，上髎 は第 5 腰椎下の高さにあたることが判明し，さら に「十四経絡発揮」帛に゙十七至二十，凡四椎，為腰 監骨，所挵附而八穸穴”として，上髎は第17椎の下， すなわち第 1 胸椎を第 1 椎とすれば，上髎は第 5 腰椎下に相当することを考証した。以上の点から 考えて，上髎の臨床的取穴においては，後仙骨孔 より 1 椎上方に定めていたと結論した。この考証 結果に対し，「内経素問次註」9)にば八或為九, 験 真骨及中造孔穴穴経, 正有八髎, 無九髎也”の記載 から八髎穴は後仙骨孔に一致するとの説が大勢を 占めていた。この説は仙骨を見たときは後仙骨孔 が八髎穴に相当すると考えたのであろうが，生体 に八䋚穴を取るときは，それより 1 椎上方に定め ていたことは明らかである。この考証結果は共同 研究者の橋口 ${ }^{10)}$ の研究に扔いても一致しているが, 本研究では近年の後仙骨孔に該当させる一般慣例 に準じて行ったものである。

近年の八䯈穴の取穴に関する主な記述は次のよ うである。上斛のみをあげる。

ア. 第 1 孔。上後腸骨棘の上 1 寸，第 1 仙骨稜 の突起下両傍 1 寸 $^{111}$

1. 第 1 孔。腸骨後上棘上端と第 1 仙骨仮棘上 突起との中間 ${ }^{5)}$

ウ. 腸骨後上棘の下方の部 ${ }^{12,13}$

工. 第 1 孔。小腸俞穴と仙骨正中線との間 ${ }^{14)}$

オ. 第 1 孔。第 5 腰椎の棘上突起尖端より尾骨 骨端を 6 等分して上の 1 等分 $^{(5)}$

力. 第 5 腰椎棘突起と正中仙骨稜上縁との間に 仮点, ここと腰僉の間で上方から $\frac{1}{4}$ の外側 2 $\mathrm{cm}^{16,17)}$

\section{V 結 論}

八䋚穴の割り込みは，まず高さについて十七椎 と仙骨角中点の長さに対し上髎は上方 $\frac{1}{4}$, 下骨は 下方 $\frac{1}{10}$ とする。次䯣・中髎はその間を 3 等分する。 次に幅については, 後正中線と後腸棘下点との長

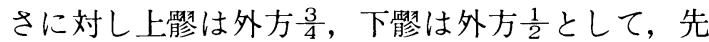
に定めた高さとの交点に定める。次䳤・中骨翏は上 髎・下髎を結ぶ斜線上で先の高さとの交点とする。

謝 辞

この研究にあたり，ご指導いただいた木下晴都博士 村居真琴博士をはじめ，X線撮影にご協力いただいた 鍼尒院・母指堂の患者各位に感謝申し上げます。

\section{参考文献}

1）著者不明：黄帝内経素問， 7 ，骨空論篇， 60 , (約B.C. $100-0)$

2）木下晴都：八零穴の位置について，日本鍼炎治 療学会論文集 4;37 54. (1955)

3）黄 甫䍀：鍼炎甲乙経，3，8.(約 280)

4）岡本一抱：十四経和語鈔，6.(1693)

5）山本新梧：日本銊炎学教科書後編，13版，関西 鍼炎学院, 大阪, (1937), p.80 81.

6）東洋療法学校協会：経穴概論，医道の日本社, 東京, (1985), p.90 92.

7）北京中医学院他：中国鍼尒学概要， 2 版，人民 衛生出版社, 北京, (1979), p.152 153.

8）滑 伯仁：十四経絡発揮，足太陽膀胱経. (1341)

9）王 水：素問次註. (762)

10）橋口利彰：八箘穴の古典とX線による位置研究, 東京医療専門学校鍼炎教員盖成科卒業論文集, 東京, (1988), p.76 87.

11）代田文誌：銊炎治療基礎学，医道の日本社，東 京, (1973), p.172 174.

12）文部省経穴調査委員：改正孔穴. (1913)

13）柳谷素霊：鍼炎医学全書 3 , 米田屋, 東京, (1940), p.153 157.

14）竹之内診佐夫, 濱添固弘：銊尒医学・経絡経穴 の近代的研究, 南山堂, 東京, (1977), p.207 209.

15）駒井一雄：経絡経穴学, 春陽堂書店, 東京, (1939), p.360 366. 
16）木下晴都, 代田文彦: 図説東洋医学, 経穴編,

学習研究社, 東京, (1975), p.300 619.

17）日本経穴委員会：経穴の名称と標準部位，20,

日本経穴委員会, 東京, (1976)

( T250 小田原市東町1-31-19)

\title{
Research on the HACHIRYO Points Using X-Ray
}

\author{
Toshiaki Hashiguchi \\ Tokyo Medical School Acupuncture Instructor Education Department \\ Haruto Kinoshita \\ Kuretake Institute Oriental Medicine Research Center
}

In recent times it is generally customary to assume that the HACHIRYO points correspond with the posterior sacral formina. In order to find a way to locate these points in accordance with this general practice we took X-rays of the sacral area of 23 subjects and conducted this study. Results showed that the standard height for the distribution of the HACHIRYO points was a point halfway between the spinous process of the 5th lumbar vertebra and the superior ridge of the middle sacral crest. We called this point the "17th vertebra". Also the midpoint between the inferior ridge of the left and right sacral angles was determined as the "sacral angle midpoint".

One-fourth of the way from the 17th vertebra to the sacral angle midpoint was considered the height of B-31. In the same area onetenth of the way from the sacral angle midpoint to the 17th vertebra was determined as the height of B-34. The area between B-31 and B-34 is divided into thirds to determine the heights of B-32 and B-33.

Next to determine the lateral distribution the area between the inferior ridge of the posteriorsuperior iliac spine and the posterior median line is used. The point laterally $3 / 4$ of the way between these which coincides with the predetermined height of B-31 is the location of B-31. Likewise the point halfway between the inferior ridge of the posterior-superior iliac spine which coincides with the determined height of B-34 is the location of B-34. Next a slanted line is used to connect B-31 and B-34. The points along this line which coincide with the previously determined heights of B-32 and B-33 are considered the locations of these points. 